\title{
Construction features of cylindrical linear asynchronous
}

\section{motors}

\author{
V. Okhrimenko \\ O.M. Beketov National University \\ of Urban economy in Kharkiv \\ Ukraine \\ E-mail: monviktor@ukr.net
}

\author{
M. Zbitnieva \\ Kharkiv Humanitarian- \\ Pedagogical Academy \\ Ukraine \\ E-mail: monviktor@ukr.net
}

\author{
Yu. Kolontaevsky \\ O.M. Beketov National University \\ of Urban economy in Kharkiv, \\ Ukraine \\ E-mail: \\ yuri_kolontaevsky@kname.edu.ua
}

\begin{abstract}
Cylindrical linear induction motors are used in the electric drive of manipulators and industrial robots due to their advantages, the main of which are simplicity of design, high manufacturability, unification of units and parts. They provide direct linear movement of the executive body of the manipulator without the use of circular to linear converters. These motors have a closed design, in which the stator winding is protected from direct environmental influences and can be sealed. They are convenient for installation, dismantling and repair.

The article describes the design features of linear asynchronous cylindrical motors. A constructive variety of engines is noted, which is due to a specific mechanism with linear movement of the executive body.
\end{abstract}

A review of literature showed that there is no single approach to the name of engines of this type. Different sources use the following names: three-phase cylindrical magnetofugal motor, coaxial linear motor, cylindrical linear asynchronous motor, tubular linear asynchronous motors.

The decomposition of the structure. The main structural elements of the engine include the following: a stator, a runner, a runner centering system and an engine cooling system. In practice, engine design options with a fixed and a movable stator are used.

In production mechanisms, the following options are used for the design of the stator magnetic circuit: longitudinal plates with grooves; continuous cross washers; transverse sets of washers alternating with stator winding coils, in which longitudinal sets of plates are installed.

The three-phase winding of the motor stator is made in the form of coils placed in the stator magnetic circuit and installed in a tubular housing.

The decomposition of the structure. The main structural elements of the engine include the following: a stator, a runner, a runner centering system and an engine cooling system. In practice, engine design options with a fixed and a movable stator are used.

In production mechanisms, the following options are used for the design of the stator magnetic circuit: longitudinal plates with grooves; continuous cross washers; transverse sets of washers alternating with stator winding coils, in which longitudinal sets of plates are installed.
The three-phase winding of the motor stator is made in the form of coils placed in the stator magnetic circuit and installed in a tubular housing.

Keywords- runner, linear induction motor, cooling system, runner centering system, stator.

\section{INTRODUCTION}

Use of linear electric motors in drives of manipulators and industrial robots, due to lack of mechanical converters of rotational motion to translational, provides a number of advantages, main of which are economy and weight and size.

Cylindrical linear induction motors (LIM) are characterized by simplicity of construction, high workability and maximum unification of units and parts. Such motors have a closed version, in which stator winding is protected from direct environmental influences and can be sealed. They are convenient for installation, dismantling and repair.

Aim of this work is to analyze constructive features of cylindrical LIM, their influence on functionality of engine and its scope.

\section{CONSTRUCTIVE FEATURES OF LIM OF CYLINDRICAL PERFORMANCE}

First cylindrical LIM was developed by L. I. Shturman [1] in 1946 and was called a three-phase cylindrical magnetofugal engine. Embodiment of this engine is shown on fig. 1. Stator of motor 1 is assembled from packages of electrical steel with annular recess (grooves) and placed in cylindrical housing 2 . Winding is made in form of set of coils 3 placed in grooves of stator. Runner 4 - cylindrical uniform

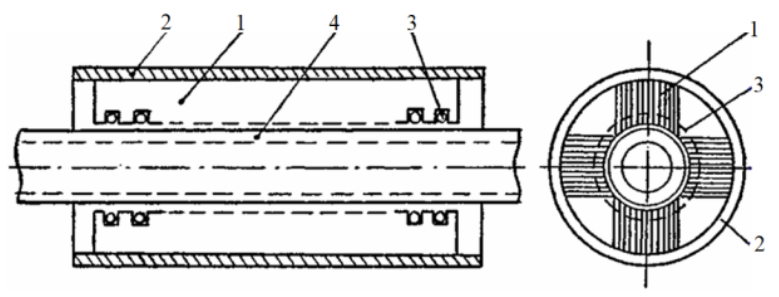

Fig. 1. L. I. Shturman design engine

Disadvantages of such engine include incomplete use of working volume of stator (presence of zones where stator magnetic circuit is absent) and high electrical resistance of runner (made of steel). 
V. Okhrimenko, M. Zbitnieva, Yu. Kolontaevsky Вип. 56, №03

I. S. Rogachev showed effectiveness of using copperplated runners (steel runner with a copper-plated surface) for engines of this type later (1948) [2].

New version of embodiment and new name for engines of this type (coaxial linear electric motor) were proposed (1960) by G. S. Kvachev.

Coaxial linear motor of construction of G. S. Kvachev is shown on fig. 2 [3, 4]. Stator housing 1 is made in form of cylinder, inside of which there are coils of stator winding 2. Between coils are placed steel washers 3 , which serve as magnetic circuit. In cLIMping nuts 4 , bronze plain bearings 5 are installed, which serve to center and set direction of movement of runner. Runner is made in form of steel rod 6, on surface of which a spiral 7 is wound from copper or aluminum wire.

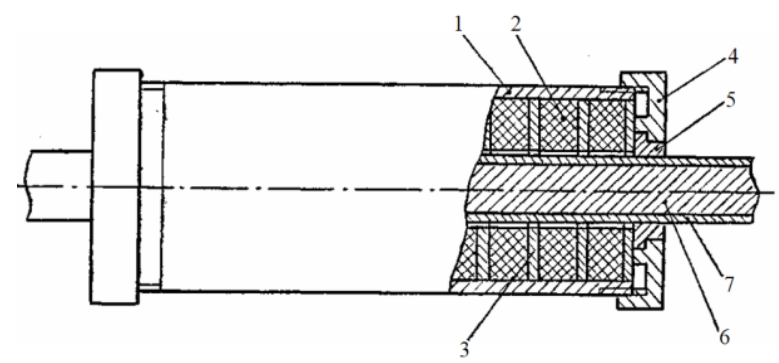

Fig. 2. G. S. Kvachev design engine

Authors of work [5] improved construction of engine (fig. 3) and gave it name "cylindrical LIM". Inductor of this engine consists of sequentially alternating flat coils 1 and packages of washers 2 , assembled from electrical steel and having grooves 3 for lay of magnetic circuit in outer diameter. Washers 2 have a cut 4 , which excludes closure of eddy currents and is used for laying of outlets of flat coils. Grooved steel is laid in grooves 3. Inductor is placed in cylindrical housing 5 .

Speed of running electromagnetic field $V_{0}$ of LIM is determined by expression

$$
V_{0}=2 \cdot \tau \cdot f
$$

where $\mathrm{f}$ - mains frequency,

$\tau-$ pole division.
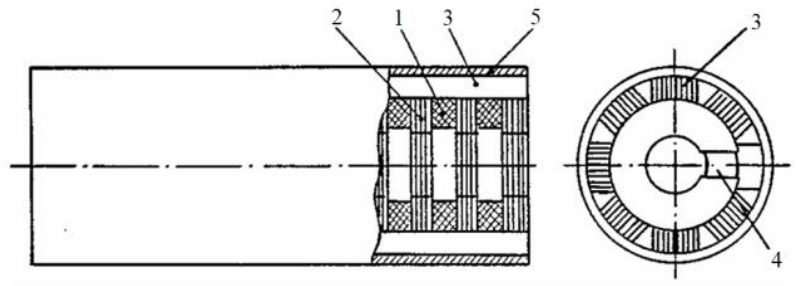

Fig. 3. Cylindrical LIM

Stator winding module of a low-speed cylindrical LIM is shown on fig. 4 [6]. Runner speed in this engine is significantly reduced by reducing pole division of stator winding. Module is assembled from two series-connected flat coils 1 and 2, wound in spiral on insulating washers 3 and 4.

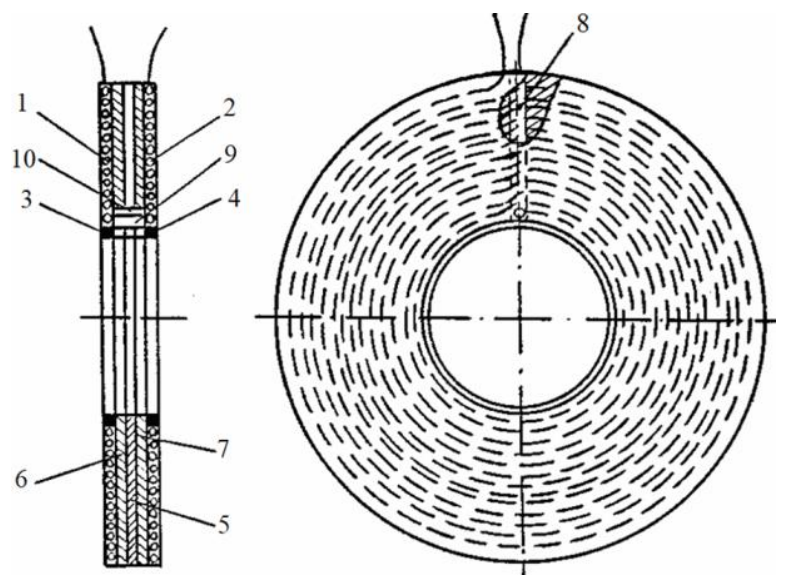

Fig. 4. Stator winding module of a low-speed cylindrical LIM

Ferromagnetic element 5 is placed between coils, separated from coils by insulating layers 6 and 7. To limit eddy currents, radial groove is made in ferromagnetic element 8 . Conductor 9 with insulation 10 is placed in groove, which connects flat coils 1 and 2. To fix coils, flat coils impregnated with adhesive. Modular coils (fig. 4) can also be made by printed wiring.

Motors of described structures (fig. 2 and fig. 3) operate in short-term mode, in drive of switching devices in particular [3, 4]. Use of these engines to drive manipulators and industrial robots operating in recursive short-time modes has necessitated change in construction of runner's centering system.

Runner centering system consists of bronze bushings 5 mounted on ends of stator 1 and acting as sliding bearings when runner 6 is moving for engine (fig. 2). Runner 6 has a copper coating 7, need for which is due to electrical considerations. When engine is operating in recursive short-time mode with large number of cycles per minute, as result of intense friction in slip bearings, phenomenon of wear of copper-coated surface of runner and surface of bronze bushing is appeared.

Cylindrical LIM was described in [7], runner of which is mounted on sliding bearings. It is coated with a layer of high-strength chrome to reduce wear on copper-plated surface of runner when the engine is in recursive short-time mode.

Engine described in [8] is shown on fig. 5. Runner of this motor moves in bearings 1 . Stator is similar to motor shown in fig. 1, consists of packages of comb plates 2 , in grooves of which cylindrical coils are placed 3 . There is fixed magnetic cylindrical core 4 inside runner through which magnetic field lines of traveling field are closed. 


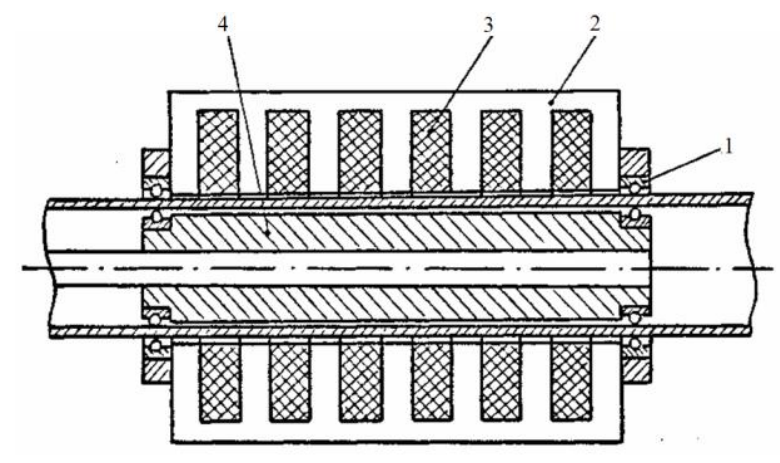

Fig. 5. Linear induction motor

Work [9] describes cylindrical LIM with external runner, device of which is shown in fig. 6. Solid stator 1 has grooves in which winding 2 is distributed. Engine has external windingless runner consisting of cylinder 3 made of magnetic material and aluminum cylinder 4 rigidly fastened to it. Longitudinal groove 5 is made for intercoil joints in stator.

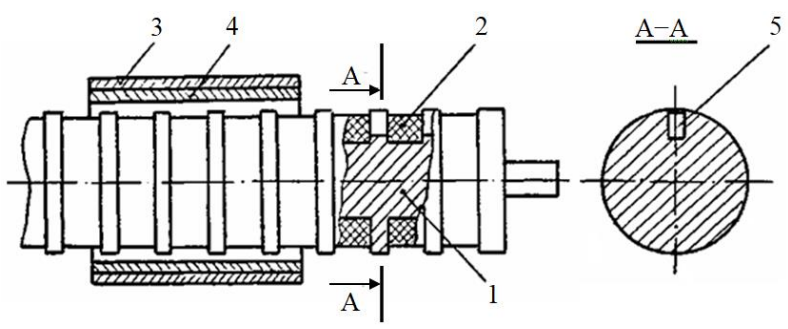

Fig. 6. Cylindrical LIM with external runner

Another solution to centering system for LIM operating in recursive short-time mode is shown in fig. 7 [10]. In this variant, brackets 1 are fixed to stator housing, on which rolling bearings 4 are mounted using bolts 2 and eccentrics 3 . Bearings are placed in collapsible clips 5 , outer surface of which is made along arc of runner's circle. Use of eccentrics 3 makes it possible to center runner relative to axis of stator. There is no friction of copper-coated surface of runner on surface of bronze sleeve in proposed construction, which eliminates phenomenon of wear.

Work of LIM with intense loads requires solving problem of increasing of intensity of engine cooling. Construction of LIM with forced air cooling system [10] is shown on fig. 8. Winding coils 2 , magnetic circuit 3 and runner 4 are placed in cylindrical housing 1 of motor stator. Cylinder 5 forming separate chamber, inside of which piston 6 mounted on runner moves is placed at one end of motor stator. Cylinder 5 is closed by cover 7 . Valve system of engine includes a valve 8 passing air from inner air channel of runner 9 to chamber 10, and valves 11 passing air from chamber 10 to chamber 12 , and then through gap $\delta$ between runner and stator into engine. Thus air is supplied that removes heat from inner surface of stator windings and outer surface of runner when electric motor is operated.

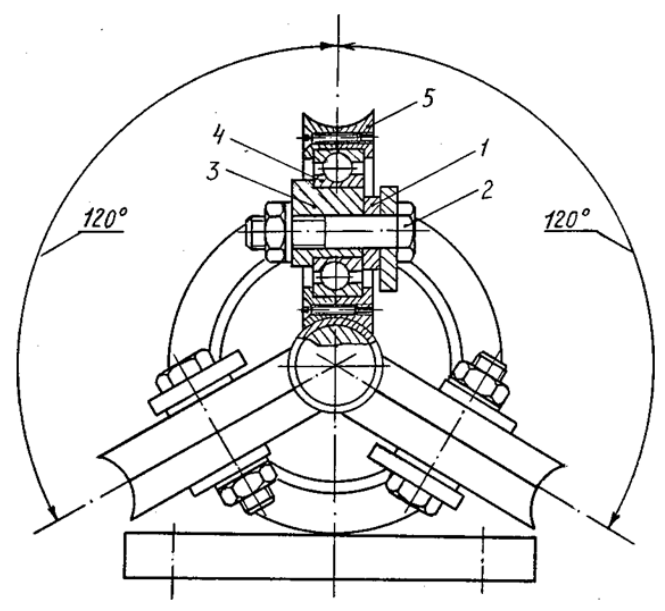

Fig. 7. LIM runner centering system

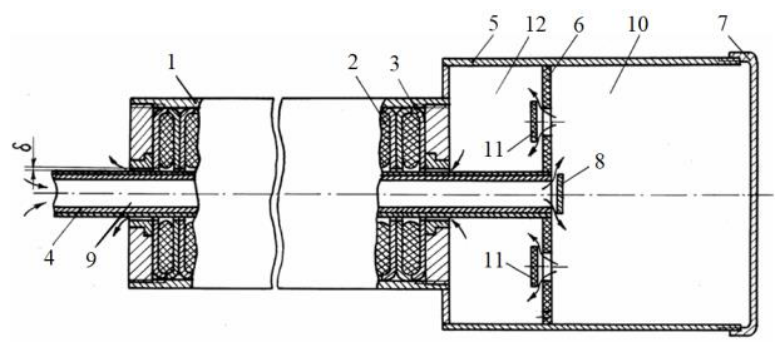

Fig. 8. LIM with forced air cooling system

A variant of forced liquid cooling system is also possible (fig. 9), which is fed through fittings 1 into space between stator housing 2 and casing 3 [10].

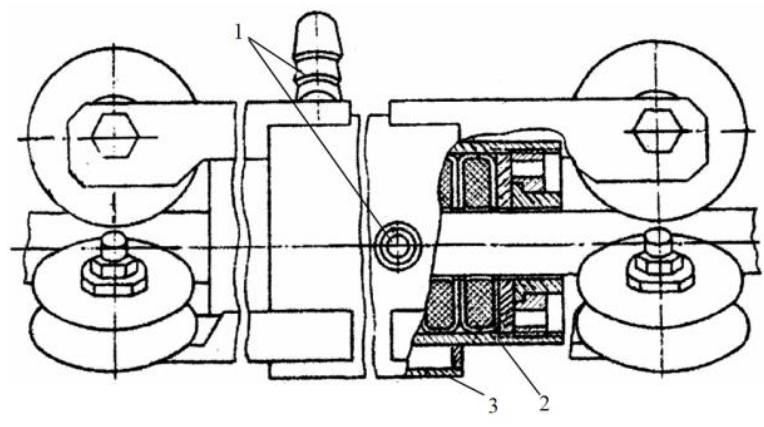

Fig. 9. LIM with water cooling system

\section{FUNCTIONALITY ANALYSIS OF CONSTRUCTIVE ELEMENTS OF LIM}

Above review shows following options for embodiment of main components of LIM of cylindrical execution.

Following options is applied during manufacture of stator:

- from longitudinal packages of comb plates, in grooves of which winding coils are laid;

- continuous transverse washers (clips) between which winding coils are located;

- windings alternating with coils, transverse sets of washers with grooves in which longitudinal sets of plates are installed; 
V. Okhrimenko, M. Zbitnieva, Yu. Kolontaevsky Вип. 56, №03

- longitudinal packs of comb plates and fixed magnetic cylindrical core inside tubular runner;

- modular execution.

It is applied during manufacture of runner:

- homogeneous steel bar;

- hollow or homogeneous steel bar coated with material with higher electrical conductivity (two-layer runner);

- two-layer runner with coating (third layer) of highstrength material to reduce wear of electrically conductive layer.

Mounting and centering system of runner is carried out using sliding bearings (guide bushings) or using rolling bearings.

Bushing of stator of magnetic circuit (motors in fig. 1 and fig. 3) allows to increase magnetic conductivity for main magnetic flux and reduce eddy current losses. However, symmetry of electromagnetic field in engine is broken with such constructive solutions, engine volume is not fully used, since there are air gaps between longitudinal packets. Part of magnetic flux passes through runner, magnetic circuit of which is not laden. As a result, energy performance of engine is getting worse.

In mass production of LIM for manipulators and industrial robots, from point of view of simplicity of construction and manufacturability, preference should be given to construction engine of G. S. Kvachev (fig. 2). These engines are characterized by axial symmetry of electromagnetic field, which reduces influence of pulsating components. Engines are produced by several factories and are used to drive busbar disconnectors in traction substations of urban electric vehicles. Increased eddy current losses in a solid stator and runner magnetic circuit do not significantly affect operation of motor, since it operates in short-term mode with a turn-on time of tenths of second.

However, runner centering system with bronze bushings is effective only in the short-term mode. Pair of copper-bronze has poor antifriction properties. Phenomenon of wear of copper-coated surface of runner and surface of bronze sleeve appears when engine is operating in recursive short-time mode with cycle time of several seconds. Axis of runner and stator are displaced, what violates axial symmetry of electromagnetic field and leads to appearance of additional radial forces that degrade energy performance of engine. In addition, radial forces contribute to wear at point of contact between runner and sleeve. Wear progresses and engine fails.

One of ways to eliminate wear is to chrome runner's copper-coated surface, i.e. application of three-layer runner: steel, copper and protective film of chromium. However, in this case, problem is partially solved, since wear of surface of sleeve remains.
Using of runner centering system shown in fig. 9, provides reliable operation of engine in recursive shorttime mode with cycle time of several seconds. Its use is justified in drives of manipulators and industrial robots. At the same time, one of described cooling systems can be used depending on intensity of engine load.

\section{CONCLUSIONS}

1. Cylindrical LIM used in drive of manipulators and industrial robots are considered.

2. Options of embodiment of main engine elements are considered: stator, runner, runner centering system, engine cooling system.

3. Analysis of influence of embodiment of main elements of engine on its functionality in short-term and recursive short-time modes is carried out.

\section{LIST OF REFERENCES}

[1] Shturman, G. I. (1946). Indukcionnye mashiny s razomknutym magnitoprovodom [Induction machines with open magnetic circuit]. Jelektrichestvo, (10), 43 - 50. [in Russian].

[2] Rogachev, I. S. (1948). Jeksperimental'noe issledovanie magnitofugal'nyh dvigatelej [Experimental study of magnetofugal motors]. Sbornik naucho-tehnicheskih statej HjeTI, (7), 214 - 231. [in Russian].

[3]. Kvachev, G. S. (1960). Certificate of authorship 131809 USSR, H02c. Jelektroprivod dlja kommutacionnyh apparatov [Electric drive for switching devices]. (Bull. № 18). [in Russian].

[4] Kvachev, G. S. \& Melnichenko G. I. (1969). Certificate of authorship 233782, USSR, H02c. Jelektroprivod dlja kommutacionnyh apparatov [Electric drive for switching devices]. (Bull. №. 3). [in Russian].

[5] Onuchin, N. B., Bondarenko, A. P. \& Vasiliev, P. V. (1973). Razrabotka $i$ issledovanie cilindrbcheskogo linejnogo asinhronnogo dvigatelja [Development and research of cylindrical linear asynchronous motor]. Izvestija vuzov. Gornyj zhurnal, (7), 132-134. [in Russian].

[6] Veselovsky, O. N. \& Poletaev, V. I. (1976). Certificate of authorship. 503340 USSR, MKI N02K 41/02, USSR. Induktor linejnogo cilindricheskogo dvigatelja [Inductor of linear cylindrical engine] (Bull. № 6). [in Russian].

[7] GB patent 1240473. Improvements in linear induction motors / Holmes N. S., Newman N. H.-K., Taylor Th.T. - mentioned on RJ. 21. Electrical engineering. - 1972. - Abstract 1I127P.

[8] US Patent 3602745. Concentric linear induction motor / Davis M. W. - mentioned on RJ. 21. Electrical engineering. - 1972. - Abstract 6I110P.

[9] Chepele, Yu.M. Cylindrical magnetofugal engine with external runner / Yu. M. Chepele // Scientific. works. Universities Lit. SSR. Electrical engineering and mechanics. - 1965. - Issue. 5 .- S. 133 164.

[10] Blazhko, Yu. M. \& Okhrimenko, V.N. (1981) Certificate of authorship 858184, USSR, H02 K 41/02. Linejnyj asinhronnyj jelektrodvigatel [Linear asynchronous electric motor]. (Bull. № 31). [in Russian]. 


\section{Конструктивні особливості циліндричних лінійних асинхронних двигунів}

В. М. Охріменко

Харківський національний університет міського

господарства ім. О.М.Бекетова Україна

\author{
М. В. Збітнева
}

Харківська гуманітарнопедагогічна академія

Україна
Ю. П. Колонтаєвський

Харківський національний університет міського господарства ім. О.М.Бекетова Україна

Лінійні асинхронні двигуни циліндричного виконання застосовують в електроприводі маніпуляторів і промислових роботів в силу їхніх переваг, основиними з яких є простота конструкції, висока технологічність виготовлення, уніфікація вузлів і деталей. Вони забезпечують безпосереднє лінійне переміщення виконавчого органу маніпулятора без застосування перетворювачів кругового руху в прямолінійний. Ці двигуни мають закрите виконання, при якому обмотка статора захищена від прямого впливу навколишнього середовища і може бути виконана герметичною. Вони зручні при монтажі, демонтажі та ремонті.

У статті розглянуті конструктивні особливості лінійних асинхронних двигунів циліндричного виконання. Відзначено конструктивне різноманіття двигунів, яке зумовлене конкретним механізмом з лінійним переміщенням виконавчого органу.

Огляд літературних джерел показав, що відсутній єдиний підхід до назви двигунів цього типу. У різних джерелах використовують такі назви: трифазний циліндричний магнітофугальний двигун, коаксіально-лінійний двигун, циліндричний лінійний асинхронний двигун, трубчастий лінійний асинхронний двигун.

До основних конструктивних елементів віднесені такі: статор, бігун, система центрування бігуна і система охолодження двигуна. Існують конструкції двигуна з нерухомим і з рухомим статором.

На практиці використовуються наступні варіанти конструктивного виконання магнітопроводу статора: поздовжні пластини $з$ пазами; суцільні поперечні шайби; поперечні набори шайб що чергуються 3 котушками обмотки статора, в яких встановлені поздовжні набори пластин.

Обмотка статора виконується у вигляді котушок, розміщених в магнітопроводі статора.

Використовуються такі конструкції бігуна двигуна: кругла однорідна сталева штанга; кругла порожня або однорідна сталева штанга 3 покриттям 3 матеріалу з високою електропровідністю (двошаровий бігун); двошаровий бігун 3 покриттям 3 високоміцного матеріалу.

Двигуни, що працюють у повторно-короткочасному режимі, мають систему центрування бігуна, яка забезпечує роботу двигуна без зносу покритої міддю поверхні бігуна. На них також застосовується система примусового охолодження.

Ключові слова - бігун, лінійний асинхронний двигун, система охолодження, система центрування бігуна, статор. 